\title{
Non-cruelty eradication of European wild rabbit Oryctolagus cuniculus from a small Mediterranean island (Isola delle Femmine, Italy)
}

Mario Lo Valvo ( $\square$ mario.lovalvo@unipa.it)

University of Palermo https://orcid.org/0000-0003-2159-5245

Francesco Lillo

Via Taino, Varese, Italy

Vincenzo Di Dio

LIPU

Research Article

Keywords: Eradication, European wild rabbit, Sicily

Posted Date: March 1st, 2022

DOI: https://doi.org/10.21203/rs.3.rs-1280846/v1

License: @ (1) This work is licensed under a Creative Commons Attribution 4.0 International License. Read Full License 


\section{Abstract}

European wild rabbit is, among mammals, one of the most widespread species almost worldwide, introduced on over 800 islands. In microinsular habitats, the introduction of alien species represents a major threat for the biodiversity, and the wild rabbit is included in the IUCN published list of the 100 worst invasive species. In 2008, an eradication plan was launched on "Isola delle Femmine", a small and uninhabited island of about 14,5 hectares, located in the Mediterranean basin and established as nature reserve in 1997 to protect its flora and vegetation. The plan was realised without the use of poison and avoiding the killing of rabbits, which were live-trapped and moved out for successive conservation projects in Sicily. The Wild Rabbit eradication plan began in December 2007 and ended in 2016, with the complete eradication of the species achieved in 2012. During the 5 years in which trapping took place on the island, a total of 799 rabbits were trapped and translocated. A significant positive correlation ( $r=$ $0.986 ; p=0.014$ ) was observed between the number of catches made during the year and the estimated rabbit density in July (considered the highest

of the year). The method used showed considerable efficacy for the management of rabbit populations in microinsular environments, highlighting the possibility of intervention with these methods when control by the use of poison or direct culling is impractical or inadvisable.

\section{Riassunto}

Il coniglio selvatico europeo è, tra i mammiferi, una delle specie più diffuse in quasi tutto il mondo risultando, tra l'altro, introdotta in oltre 800 isole. Negli habitat microinsulari l'introduzione di specie aliene rappresenta una grande minaccia per la biodiversità ed il coniglio selvatico è incluso nella lista pubblicata dalla IUCN delle 100 peggiori specie invasive. Nel 2008 è stato avviato un piano di eradicazione su "Isola delle Femmine", una piccola isola disabitata di circa 14,5 ettari, situata nel bacino del Mediterraneo e istituita come riserva naturale nel 1997 per proteggere la sua flora e vegetazione. Il piano è stato realizzato senza l'uso di veleno ed evitando l'uccisione dei conigli che sono stati catturati vivi e trasferiti per successivi progetti di conservazione in Sicilia. Il piano di eradicazione del coniglio selvatico è iniziato nel dicembre 2007 e si è concluso nel 2016 , con la completa eradicazione della specie raggiunta nel 2012. Durante i cinque anni in cui la cattura ha avuto luogo sull'isola, un totale di 799 conigli sono stati catturati e traslocati. Una significativa correlazione positiva $(r=0,986 ; p=0,014)$ è stata osservata tra il numero di catture effettuate durante l'anno e la densità di conigli stimata in luglio (considerata la più alta dell'anno). II metodo utilizzato ha mostrato una notevole efficacia per la gestione delle popolazioni di conigli in ambienti microinsulari, evidenziando la possibilità di intervenire con questi metodi quando il controllo tramite l'uso del veleno o l'abbattimento diretto è impraticabile o sconsigliabile.

\section{Introduction}

The introduction of alien species represents a major threat for native fauna and flora, especially in microinsular habitats, causing declines and extinctions because of the lack of natural defences against invaders (Atkinson 1989, 2001; Williamson 1996; Courchamp et al. 2003). Significant impacts may occur because of the introduction of plants (Affre et al. 2010), predators (Croll et al. 2005; Fukami et al. 2006; Towns et al. 2009; Wardle et al. 2009) and herbivores (Martín-Esquivel et al. 2020) by an alteration of the structure and function of ecosystems.

European wild rabbit (Oryctolagus cuniculus) is one of the most widespread mammal species almost worldwide. It is native to the Iberian Peninsula and, probably, southern France (Lopez-Martinez 1989, 2008; Rogers et al. 1994; Kaetzke et al. 2003), and its spreading and distribution have mainly been influenced by humans (Clutton-Brock 1981; Flux 1994; Callou 1995), especially for its traditional importance as a small game species. It is present in Europe, North Africa, South America, Australia and New Zealand (Ferrand 2008) and has also been widely introduced on over 800 islands (Flux and Fullagar 1992), where it is highly destructive (Watson 1961; Brothers 1984; Flux and Fullagar 1992; Williams et al. 1995; Courchamp et al. 2003). European wild rabbit can alter natural habitats through its ecosystem engineering activity by direct effects on vegetation cover and accelerating erosion processes (Chapuis et al. 1994; Copson and Whinam, 1998; Priddel et al. 2000; Gálvez-Bravo et al. 2011).

As a pest species, European wild rabbit is included in the IUCN published list of the 100 worst invasive species (Global Invasive Species Database, 2020), and several attempts have been made for its eradication from some islands to benefit local biodiversity and ecosystem recovery (Priddel et al. 2000; Murphy et al. 2010).

"Isola delle Femmine" is a small island in the Mediterranean basin, established as a protected area in 1997 for the conservation of flora and vegetation. After the Second World War, as well as a small herd of sheep, several rabbits belonging to the subspecies 0 . c. cuniculus (Lo Valvo et al. 2014,2017 ) have been voluntarily introduced on this island by humans for hunting purposes. After their introduction, the density of rabbits on the island was kept low because of hunting, but the establishment of the protected area resulted in a hunting ban, beyond the end of competition for access to trophic resources caused by the eradication of domestic livestock. Therefore, the combined absence of natural predators and the abundant presence of herbaceous plants, the wild rabbit population reached and maintained high densities. This has resulted in a significant negative impact on the natural vegetation and soil morphology due to burrowing and grazing, with a deterioration in the conservation status of the protected area.

To avoid the detrimental effect caused by European wild rabbit on conservational goals of the protected area, since 2008, an eradication program has been in place on the island.

This program, approved by the Istituto Superiore per la Protezione e Ricerca Ambientale (ISPRA) and applied for the first time in Italy, was realised, with success, only by live-trapping and moving the rabbits from the island, thus avoiding the use of poison and/or firearms, as carried out on other 
islands, which could have disturbed the island's flora and fauna. This paper reports the technique and the results achieved.

\section{Material And Method}

Isola delle Femmine (Sicily, province of Palermo, Southern Italy: $38.211^{\circ} \mathrm{N} 13.235^{\circ} \mathrm{E}$ ), built by mesozoic stratified limestones (Catalano et al. 2013 ), is a small uninhabited island of about 14.5 ha (0-36.8 m a.s.I.), located $400 \mathrm{~m}$ away from the northwest coast of Sicily (Fig. 1). It can only be reached by a small boat at favourable sea conditions. Since 1997, the entire island has been a dedicated Nature Reserve, established by the Regional Sicilian Government. It is also a "Special Area of Conservation", protected under the European Union Directive 92/43/ EEC, better known as "Habitat Directive" (code SAC/ZSC ITA020005).

The island is almost totally covered with forbs and scrubs typical of Mediterranean scrubland, including Pistacia lentiscus, Thymelaea hirsuta and Chamaerops humilis (Di Martino and Trapani 1964; Caldarella et al. 2010). Vascular plants of the island mainly include therophytes ( 62\%), hemicryptophytes ( 20\%), geophytes ( 9\%), chamaephytes ( 5.5\%), nanophanerophytes $(\sim 2.3 \%)$ and phanerophytes ( 1.8\%). Regarding chorotypes, the Mediterranean one is the most widespread one ( 33\%). There is a wide range of floristic components (cosmopolite, subcosmopolite and xenophyte species), with 39 entities, $17.8 \%$ of the total plant taxa on the island. The endemic and subendemic contingents are represented by six taxa, i.e. $2.7 \%$ of the total (e.g. endemic taxa of north-western Sicily: Limonium bocconei and Romulea linaresii subsp. linaresii). Other endemic taxa have a regional (e.g. Allium lehmani), extra-regional Thyrrenian (Biscutella maritima) or South Italian distribution (Carlina sicula subsp. sicula). Other rare species, whose extent of occurrence is not limited to Sicily, include Delphinium emarginatum subsp. emarginatum, Galium verrucosum subsp. halophilum, Jacobaea delphinipholia and Ononis pendula subsp. boissieri (Caldarella et al. 2010).

The only building on the island is a late-medieval tower ruin, along with a few stone tanks for fish keeping (Riggio and Raimondo 1992), dating back to the 4th century B.C. (La Rocca 2004) and today no longer used.

Since the 1988, the Mediterranean yellow-legged gull Larus michahellis has been breeding on the island (Lo Valvo et al. 1993), with a current estimated 500 pairs (LIPU 2007). Among other vertebrate species, the Italian wall lizard Podarcis siculus and the black whip snake Hierophis viridiflavus are present. Prior to the eradication programme, Norway rats (Rattus norvegicus) and introduced European wild rabbits were present since after the Second World War.

The Wild Rabbit eradication programme was carried out exclusively using the live-trapping method. This technique was chosen to avoid the circulation of poison within the delicate microinsular ecosystem and because the control of fauna with the use of poison is prohibited by regional legislation.

The commencement of the trapping activities was determined by the marine weather conditions, which had to remain good for prolonged periods of time to allow easy and constant landing on the island. For each annual session, trapping activities were only interrupted after the prolonged absence of catches (at least 10 consecutive days) or when rainfall stimulated vegetative recovery of the herbaceous flora or when autumn weather conditions (September) prevented regular visits to the island.

The steel trap cages, measuring $30 \times 30 \times 70 \mathrm{~cm}$ and with a snap closure mechanism activated by a tilting platform at the bottom of the trap, were evenly distributed over the entire surface of the island, at an average distance of about $40 \mathrm{~m}$ from each other. The position of each trap was georeferenced with GPS to facilitate its location and to facilitate cartographic positioning. Each trap was covered with shade netting to avoid stress to the trapped animals as a result of the strong sunlight and to ensure a protected environment before translocation.

The traps were set with fresh fruit, replaced periodically every 2-3 days. In particular, according to seasonal availability, Canary melons, apples or grapes were used. Starting from the third year of trapping, the traps were placed taking into account the presence of traces on the ground of the presence of rabbits (faecal pellets, burrows), taking care to change the position of traps that did not catch for more than 10 days.

On the island, captured animals were initially housed in pet carriers in a shaded and protected collection point. Once the control session of all traps was concluded, the captured animals were transferred on the mainland to a temporary breeding and storage centre for fauna (Istituto Zootecnico Sperimentale per la Sicilia) before being used, after the appropriate health checks, for restocking interventions on the Sicilian territory, where the species, considered para-autocthonous, has been undergoing a strong decline in the last decades (Lo Valvo et al. 2017; Di Vittorio et al. 2019).

Simultaneously, censuses of the rabbit population were conducted using the faecal bullet count method (Eberhardt and Van Etten 1956; Moreno and Villafuerte 1995; Redondo 2009) to assess and monitor density changes during the trapping phase of each year.

\section{Results}

The wild rabbit eradication plan began in 2008 and ended in 2016, with the complete eradication of the species already achieved in 2012 . In fact, since 2013, no rabbits have been caught or observed, and no traces (faeces or active burrows) have been found. To verify the absence of rabbits on the island, inspections were carried out between 2013 and 2016 with hunting dogs equipped with "antivenom bites" to prevent negative interactions with wildlife. These inspections confirmed the absence of the target species. 
Trapping periods were between April and October, consistent with weather and sea conditions suitable for landing on the island in reasonable safety. During the eight of activity, a variable number of trap cages was used, from a minimum of 47 traps to a maximum of 104 traps, in relation to the estimated frequency of catches, with a variable density of 3.2 to 6.9 traps/ha.

During the 5 years in which trapping took place on the island, a total of 799 rabbits were trapped and translocated. The start and end dates of trapping activities, the total number of animals caught and traps used, together with the trapping effort, are shown in Table 1.

Table 1

start and end dates of trapping activities, total number of animals caught and traps used, trapping effort

\begin{tabular}{|llllllll|}
\hline Year & Start & End & Rabbits & n. days & n. traps (C) & trapping effort (B*C) & trapping efficiency \\
caught (A) & $(B)$ & & & A/C \\
\hline 2008 & 1 April & 22 September & 133 & 174 & 47 & 8.178 & 0,02 \\
\hline 2009 & 8 April & 21 September & 106 & 166 & 67 & 11.122 & 0,01 \\
\hline 2010 & 17 May & 1 October & 297 & 137 & 72 & 9.864 & 0,03 \\
\hline 2011 & 18 June & 28 September & 263 & 102 & 100 & 10.200 & 0,03 \\
\hline 2012 & 28 May & 21 September & 1 & 118 & 104 & 12.272 & 0,00009 \\
\hline 2013 & 6 September & 2 October & 0 & 27 & 97 & 2.619 & 0 \\
\hline 2014 & 1 August & 15 September & 0 & 46 & 98 & 4.508 & 0 \\
\hline 2015 & 22 July & 21 August & 0 & 31 & 98 & 3.038 & 0 \\
\hline 2016 & 3 August & 12 September & 0 & 41 & 98 & 4.018 & 0 \\
\hline
\end{tabular}

During the application of the wild rabbit eradication plan, apart from the capture of a single individual blackbird (Turdus merula), individuals of Mediterranean yellow-legged gull (Larus michahellis) and Norway rat (Rattus norvegicus) were also captured (Table 2). After capture, the gulls and blackbird were released, whereas the rats were generally found dead when trying to escape.

Table 2

Species and number of specimens captured during the application of the wild rabbit

\begin{tabular}{|lllll|}
\hline \multicolumn{5}{c}{ eradication plan } \\
\hline rabbits & 133 & 106 & 297 & 263 \\
\hline rats & 122 & 0 & 0 & 0 \\
\hline gulls & 26 & 60 & 97 & 69 \\
\hline
\end{tabular}

The monthly values of population densities, estimated during the years in which catches were made by applying the Moreno and Villafuerte (1995) algorithm, are shown in Table 3. In all years, decreases were observed, with densities at the end of the campaign (September) always lower than 2.5 ind/ha.

Table 3

Trend of densities and estimated rabbit population during trapping years.

\begin{tabular}{|c|c|c|c|c|c|c|c|c|c|c|}
\hline & 2008 & & 2009 & & 2010 & & 2011 & & 2012 & \\
\hline & rabbit/ha & $\begin{array}{l}\text { estimated } \\
\text { population }\end{array}$ & rabbit/ha & $\begin{array}{l}\text { estimated } \\
\text { population }\end{array}$ & rabbit/ha & $\begin{array}{l}\text { estimated } \\
\text { population }\end{array}$ & rabbit/ha & $\begin{array}{l}\text { estimated } \\
\text { population }\end{array}$ & rabbit/ha & $\begin{array}{l}\text { estimated } \\
\text { population }\end{array}$ \\
\hline April & 12,18 & 177 & & & & & & & & \\
\hline May & 8,37 & 121 & & & & & & & 0,43 & 6 \\
\hline June & 7,14 & 104 & & & 18,61 & 270 & 14,35 & 208 & & \\
\hline July & 6,47 & 94 & 4,83 & 70 & 10,07 & 146 & 9,41 & 136 & & \\
\hline August & 3,58 & 52 & 1,63 & 24 & 3,69 & 54 & 3,61 & 52 & & \\
\hline September & 2,32 & 34 & 0,71 & 10 & 0,8 & 12 & 1,7 & 25 & & \\
\hline
\end{tabular}

A significant positive correlation ( $r=0.986 ; p=0.014)$ was observed between the number of catches made during the year and the estimated rabbit density in July (considered to be the highest of the year). When possible, the number of rabbits caught, and therefore subtracted from the island's 
population, was correlated with the estimated number of rabbits removed, the latter calculated as the differences between the mean density values between two temporally consecutive counts. The correlation was statistically significant $(r=0.83 ; p=0.003)(F i g$. 2).

No significant correlations were found between the number of rabbit catches and the number of traps used $(r=0.80 ; p=0.20)$, between the number of catches and the number of trapping days $(r=0.63 ; p=0.37)$ and between the number of catches and trapping effort (days $x$ traps) $(r=0.05 ; p=0.95)$. Similarly, no significant correlations were found between the total number of catches of all species caught and the number of traps used $(r=0.58 ; p=$ $0.42)$, between the total number of catches of all species caught and the number of trapping days $(r=0.32 ; p=0.68)$ and between the number of catches and trapping effort (days $x$ traps) $(r=0.35 ; p=0.64)$.

\section{Discussion}

Globally, several wild rabbit eradication efforts have been carried out on islands (Clout and Williams 2009; Genovesi and Carnevali 2011). Using the Database of Island Invasive Species Eradications (DIISE 2018), there have been 137 rabbit eradication attempts globally on islands, of which 108 have been successful. The methods used to eradicate rabbits have been diverse, often in combination, and have mainly involved the use of poison (48), firearms (23), pathogen input (11), traps (14), unknown (39). Only in three cases, trapping was used as the only method for rabbit eradication: Montana Clara Island (Canary, Macaronesia) (Martìn 2002), Kaua`i Island (Hawai, United States) (Hess and Jacobi 2011) and Molara Island (Sardinia, Italy) (Sposimo et al. 2010). Unfortunately, no detailed information is reported for any of the three that would allow a comparison.

As far as Isola delle Femmine is concerned, although Capizzi (2020) writes of failure, the eradication of the wild rabbit using only the trapping method was successful. Although the plan was applied for eight consecutive years, eradication was achieved definitively after five years, and to date, there are no more rabbits on the island.

The longer time taken to achieve complete eradication, compared to other interventions where other techniques were used (DIISE 2018), was rewarded by not having to use poison, which could have had possible negative effects on the ecosystem of a microinsular protected area, and by avoiding the killing of the animals, with possible negative reactions from the public as the captured rabbits were used for restocking purposes.

The experience gained over the years has made it possible to reduce the trapping effort, developing more effective methods in term of the number of catches made during the summer months. In fact, trapping actions have proved to be of little or no benefit in the presence of rain and mild temperatures, combined with the availability of fresh pasture. Under these conditions, rabbits were unlikely to be enticed by the bait in the traps.

The lack of a significant correlation between the number of catches and trapping effort could be due to the low number of degrees of freedom, but probably, even more so, to the different numbers of rabbits in the population mong the years in which the catches were made. For example, on the island, in July 2011, the number of rabbits (136) was estimated to be almost double (70) the number estimated for the same month in 2009 (Table 3 ).

Instead, trapping effort is likely to affect trapping efficiency in general. As Figure 3 shows, since 2009, the increase in trapping probability as a result of rat eradication (cf. Canale et al. 2019) has been offset by the increase in the capture of herring gull individuals, especially juveniles, which are captured in abundance until mid-July. When both juvenile and adult gulls drastically reduce their frequentation of the island, the number of traps available to catch rabbits increases. The constant movement of the traps in relation to the signs of presence seems to have been decisive for the success, resulting in an average daily trapping efficiency per trap of 0.03 rabbits (see Table 1 ), which was therefore sufficient for the eradication of a population with a density of between 15 and 18.5 animals per hectare. The results also showed that the pellet count technique is an excellent method of absolute estimation for this species.

In conclusion, under certain conditions, in a microinsular environment, the only trapping method using strategically placed traps in relation to signs of presence can also be applied alone as an effective management method for the control or eradication of feral rabbit populations, especially when the use of poison or the direct killing of individuals are impractical or inadvisable.

\section{Declarations}

\section{Acknowledgements}

The project has been funded by Assessorato del Territorio e dell'Ambiente della Regione Siciliana. The following public bodies have contributed, each for their own competence, to the smooth running of the activities: Istituto Superiore per la Protezione e Ricerca Ambientale, Osservatorio faunistico della Regione Siciliana, Ripartizione faunistica di Palermo, Istituto Sperimentale Zootecnico per la Sicilia, Istituto Zooprofilattico Sperimentale della Sicilia, Azienda Sanitaria Provinciale di Palermo, Distretto di Carini, Unità Operativa di Prevenzione Veterinaria. Authors wont to thank: Nature Reserve staff, students and volounteers working on the island for their qualified field work; Antonino Camarda, Lucio Insinga, Casimiro Li Vigni for having amicably made their hunting dogs available to carry out surveys to estimate the possible presence of rabbits.

\section{Authors' contributions}




\section{Funding}

This work was supported by Assessorato del Territorio e dell'Ambiente della Regione Siciliana

\section{Declarations}

Raw data are available upon request to the correspondent author

\section{Conflicts of interest}

The authors declare that they have no conflict of interest

\section{Author Contributions}

All authors contributed to the study conception and design. All authors read and approved the final manuscript.

\section{References}

1. Affre L, Suehs CM, Charpentier S, Vilà M, Brundu G, Lambdon P, Traveset A, Hulme PE (2010) Consistency in the habitat degree of invasion for three invasive plant species across Mediterranean islands. Biological Invasions 12 (8), pp. 2537-2548.

2. Atkinson IAE (1989) Introduced animals and extinctions. Conservation for the twenty-first century (Western D and Pearl MC, eds.). Oxford University Press, New York. Pp. 54-79.

3. Atkinson IAE (2001) Introduced mammals and models for restoration. Biol. Conserv., 99: 81-96.

4. Brothers NP (1984) Breeding distribution and status of burrownwsting birds at Macquarie Island. Australian Wildlife Reaserch II, $113-131$.

5. Caldarella O, La Rosa A, Pasta S, Di Dio V (2010) La flora vascolare della riserva naturale orientata Isola delle Femmine (Sicilia NordOccidentale): aggiornamento della check-list e analisi del turnover. Naturalista Siciliano, 34: 421-476.

6. Callou C (1995) Modifications de l'aire de répartition du Lapin (Oryctolagus cuniculus) en France et en Espagne, du Pléistocéne à l'époque actuelle. Ètat de la question. Anthropozoologica, 21: 95-114.

7. Canale DE, Di Dio V, Massa B, Mori E (2019) First successful eradication of Norway rats Rattus norvegicus from a small Mediterranean island (Isola delle Femmine, Italy). Folia Zoologica, 68: 21-26.

8. Capizzi D (2020) A review of mammal eradications on Mediterranean islands Mammal Review, 50 (2), pp. 124-135.

9. Catalano R, Basilone L, Di Maggio C, Gasparo Morticelli M, Agate M \&Avellone G (2013). Carta Geologica d'Italia alla scala 1:50.000 PartinicoMondello, ISPRA.

10. Chapuis JL, Boussès P, Barnaud G (1994) Alien mammals, impact and management in the French subantarctic Islands. Biological Conservation, 67: $97-104$

11. Clout MN, Williams P (2009) Invasive Species Management: A Handbook of Principles and Techniques. Techniques in Ecology and Conservation Series. Oxford and New York: Oxford University Press

12. Clutton-Brock J (1981) Domestic Animals from Early Times (Heinemann and Br. Mus. of Nat. Hist., London).

13. Copson GR, Whinam J (1998) Response of vegetation on subantarctic Macquarie Island to reduced rabbit grazing. Aust. J. Bot.: $46: 15-24$.

14. Courchamp F, Chapuis J-L, Pascal M (2003) Mammal invaders on islands: impact, control and control impact. Biol. Rev., 78: $347-383$.

15. Croll DA, Maron JL, Estes JA, Danner EM, Byrd GV (2005) Introduced predators transform subarctic islands from grassland to tundra. Science, 307: 1959-1961.

16. DIISE (2018) The Database of Island Invasive Species Eradications, developed by Island Conservation, Coastal Conservation Action Laboratory UCSC, IUCN SSC Invasive Species Specialist Group, University of Auckland and Landcare Research New Zealand.

http://diise.islandconservation.org

17. Di Martino A, Trapani S (1964) Flora e vegetazione dell'Isola delle Femmine. Lav. Ist. bot. Giard. colon. Palermo, 20: $121-159$.

18. Di Vittorio M, Lo Valvo M, Di Trapani E, Sanguinetti A, Ciaccio A, Grenci S, Zafarana M, Giacalone G, Patti N, Cacopardi S, Rannisi P, Scuderi A, Luiselli L, La Grua G, Cortone G, Merlino S, Falci A, Spinella G, López-López P (2019) Long-term changes in the breeding period diet of Bonelli's eagle (Aquila fasciata) in Sicily, Italy. Wildlife Research, 46(5): 409-414.

19. Eberhardt L \& Van Etten RC (1956) Evaluation of the pellet group count as a deer census method. J. Wildl. Manage., $20: 70-74$.

20. Ferrand $N$ (2008) Inferring the evolutionary history of the European rabbit (Oryctolagus cuniculus) from molecular markers. In: Lagomorph Biology: Evolution, Ecology and Conservation (eds Alves PC, Ferrand N, Hacklander K). Springer, Amsterdam, The Netherlands.

21. Flux JEC, Fullagar PJ (1992) World distribution of the rabbit Oryctolagus cuniculus on islands. Mammal Rev., 22: 151-205.

Page 6/8 
22. Flux JEC (1994) World distribution. In: Thompson HV, King CM (eds). The European rabbit. Oxford Science Publications, Oxford, United Kingdom, 8-21.

23. Fukami T, Wardle DA, Bellingham PJ, Mulder CPH, Towns DR, Yeates GW, Bonner KI, Durrett MS, Grant-Hoffman MN, Williamson WM (2006) Above-and below-ground impacts of introduced predators in seabird-dominated island ecosystems. Ecol. Lett., 9: $1299-1307$.

24. Gálvez-Bravo L, López-Pintor A, Rebollo S, Gómez-Sal A (2011) European rabbit (Oryctolagus cuniculus) engineering effects promote plant heterogeneity in Mediterranean dehesa pastures. Journal of Arid Environments, 75: 779-786.

25. Genovesi P, Carnevali L (2011) Invasive alien species on European islands: eradications and priorities for future work. Pages 56-62 In: Veitch CR, Clout MN and Towns DR (eds.). Island invasives: eradication and management. IUCN, Gland, Switzerland.

26. Global Invasive Species Database (GISD) (2020). Downloaded from http://www.iucngisd.org/gisd/100_worst.php on 23-02-2020

27. Kaetzke P, Niedermeier J, Masseti M (2003) Oryctolagus cuniculus (Linné 1758) Europäisches Wildkanichen. In: Krapp F (ed) Handbuch der Säugetiere Europas. Hasentiere, AulaVerlag, Wiebelsheim, Germany, 187-289.

28. Hess SC, Jacobi JC (2011) The history of mammal eradications in Hawai'i and the United States associated islands of the Central Pacific. In: Veitch CR, Clout MN, Towns DR (Eds.), Island Invasives: Eradication and Management. IUCN, Gland, Switzerland, pp. 67-73.

29. La Rocca R (2004) Isola delle Femmine un'ipotesi di un insediamento economico polifunzionale ed autosufficiente per la lavorazione del pescato. Sicilia Archeologica, 102: 170-185.

30. LIPU (Lega Italiana Protezione Uccelli) (2007) Final report 2007 Isola delle Femmine Nature Reserve Relazione Tecnica dell'Ente Gestore LIPU Onlus, Regione Siciliana-Assessorato Territorio e Ambiente.

31. López-Martínez N (1989) Revision sistemática y biostratigráfica de los lagomorphos (Mammalia) del terciario y cuaternario de España. Mem. Mus. Paleontol. Univ. Zaragoza: 31-343.

32. López - Martínez N (2008) The Lagomorph Fossil record and the origin of the European Rabbit. In: Alves PC, Ferrand N, Hackländer K (eds). Lagomorph biology: evolution, ecology, and conservation. Springer, Berlin, Heidelberg, Germany, 2746.

33. Lo Valvo M, La Scala A, Scalisi M (2014) Biometric characterisation and taxonomic considerations of european rabbit Oryctolagus cuniculus (Linnaeus 1758) in Sicily (Italy). World Rabbit Sci., 22: 207-214.

34. Lo Valvo M, Russo R, Mancuso FP, Palla F (2017) mtDNA diversity in rabbit population from Sicily (Italy). Turkish Journal of Zoology, 41: 645653.

35. Lo Valvo M, Massa B, Sarà M (1993) Uccelli e paesaggio in Sicilia alle soglie del terzo millennio. Naturalista sicil., 17 (suppl.): 1-376.

36. Martìn A (2002) Rabbit Eradication on Montaña Clara (Canary Islands, Spain). Proceedings of the Workshop on Invasive Alien Species on European Islands and Evolutionary Isolated Ecosystems and Group of Experts on Invasive Alien Species (Horta, Azores). Council of Europe, Strasbourg, tpvs/IAS (2002)2, pp 14-15.

37. Martín-Esquivel, JL, Marrero-Gómez M, Cubas J, González-Mancebo JM, Olano JM, del Arco M (2020) Climate warming and introduced herbivores disrupt alpine plant community of an oceanic island (Tenerife, Canary Islands) Plant Ecology, 221 (11), pp. $1117-1131$.

38. Murphy E, Crowell M, Henderson W (2010) Workshop Proceedings: Improving the Efficiency of Rabbit Eradications on Islands. 4-5, February, Christchurch. Invasive Animals Cooperative Research Centre, Canberra.

39. Moreno S, Villafuerte R (1995) Traditional management of scrubland for the conservation of rabbits Oryctolagus cuniculus and their predators in Doñana national park, Spain. Biological Conservation, 73: 81-85.

40. Priddel D, Carlile N, Wheeler R (2000) Eradication of European rabbits (Oryctolagus cuniculus) from Cabbage Tree Island, NSW, Australia, to protect the breeding habitat of Gould's petrel (Pterodroma leucoptera leucoptera). Biol. Conserv., 94: 115-125.

41. Redondo P G (2009) Number of faecal pellets dropped daily by the wild rabbit (Oryctolagus cuniculus). Journal of Animal and Veterinary Advances, 8: 2635-2637.

42. Riggio S, Raimondo FM (1992) Proposta di una riserva costiera per la tutela e la valorizzazione dei biotopi di Isola delle Femmine e di Monte Gallo (Palermo). Quad. Bot. Amb. Appl., 2: 59-96.

43. Rogers PM, Arthur CP, Soriguer RC (1994) The rabbit in continental Europe. In: Thompson HV and King CM (eds). The European rabbit. Oxford Science Publications, Oxford, U.K., 22-63.

44. Sposimo P, Spano G, Navone A, Fratini S, Ragionieri L, Putzu M, Capizzi D, Baccetti N (2012) Rodent eradication on Molara Island and surrounding islets (NE Sardinia): from success to the riddle of reinvasion. Aliens Bulletin, 32: 30-38.

45. Towns DR, Wardle DA, Mulder CPH, Yeates G, Fitzgerald BM, Parrish GR, Bellingham PJ, Bonner KI (2009) Predation of seabirds by invasive rats: multiple indirect consequences for invertebrate communities. Oikos, 118: 420-430.

46. Watson JS (1961) Feral Rabbit populations on pacific islands. Pacific Science 15, pp. 591-593.

47. Wardle DA, Bellingham PJ, Bonner KI, Mulder CPH (2009) Indirect effects of invasive predators on litter decomposition and nutrient resorption on seabirddominated islands. Ecology, 90: 452-464.

48. Williams K, Parer I, Coman B, Burley J, Braysher M (1995) Managing Vertebrate Pests: Rabbits. Australian Government Publishing Service, Canberra. 


\section{Figures}

\section{Figure 1}

Map of the location of the nature reserve "Isola delle Femmine" (Sicily, Southern Italy)

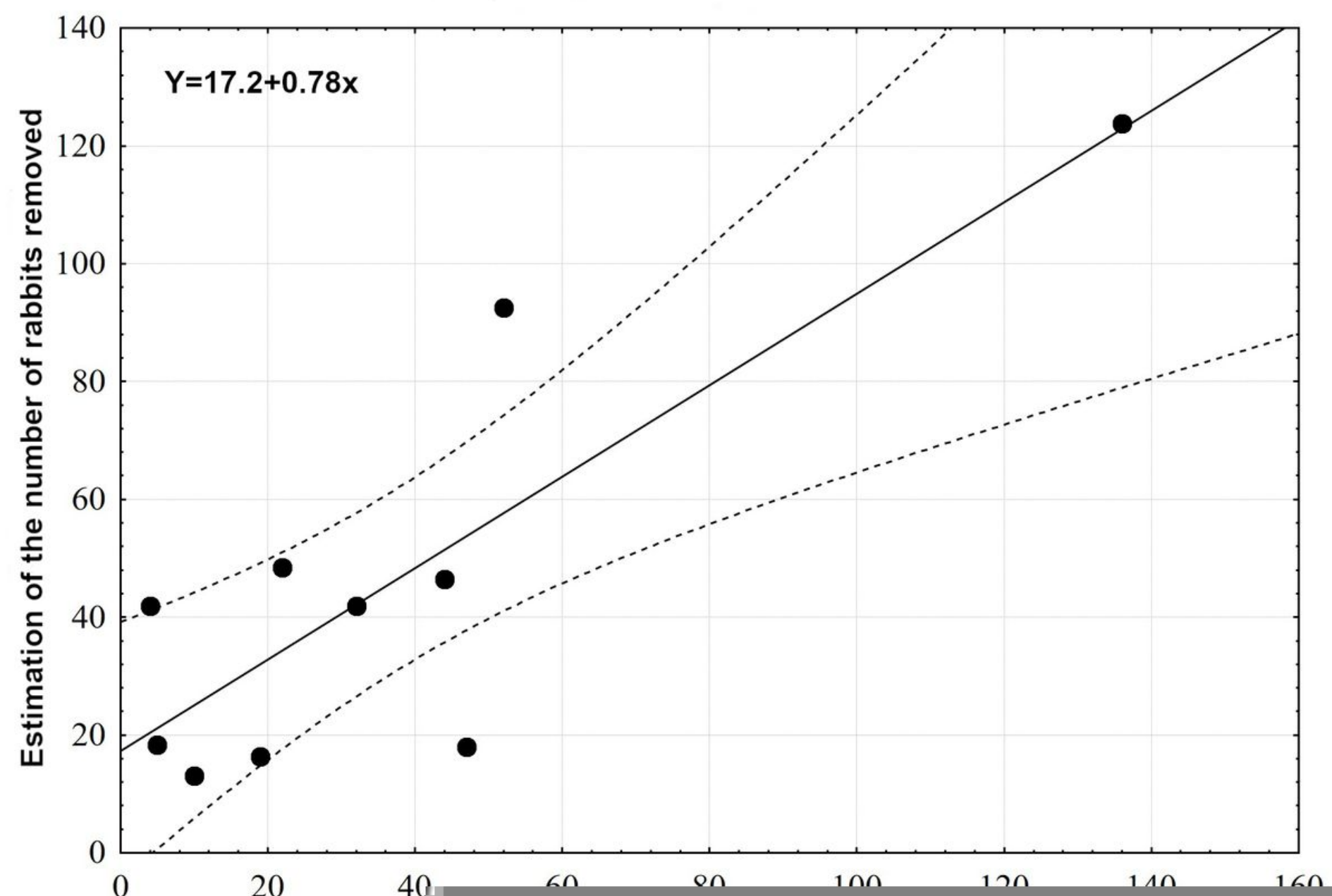

Figure 2

Relationships between the number of catches made during the year and the estimated rabbit density in the month of July.

\section{Figure 3}

trends in rabbit, rat and seagull catches during the rabbit eradication plan in the nature reserve "Isola delle Femmine" (Sicily, Italy). 